\title{
Community-level response of fish larvae to environmental variability in the southeastern Bering Sea
}

\author{
Elizabeth C. Siddon ${ }^{1, *}$, Janet T. Duffy-Anderson ${ }^{2}$, Franz J. Mueter ${ }^{1}$ \\ ${ }^{1}$ University of Alaska Fairbanks, School of Fisheries and Ocean Sciences, Juneau, Alaska 99801, USA \\ ${ }^{2}$ RACE Division, Recruitment Processes Program, Alaska Fisheries Science Center, National Marine Fisheries Service, \\ National Oceanic and Atmospheric Administration, Seattle, Washington 98115, USA
}

\begin{abstract}
Oceanographic conditions in the southeastern Bering Sea are affected by large-scale climatic drivers (e.g. Pacific Decadal Oscillation, Aleutian Low Pressure System). Ecosystem changes in response to climate variability should be monitored, as the Bering Sea supports the largest commercial fishery in the USA (walleye pollock Theragra chalcogramma). This analysis examined shifts in larval fish community composition in the southeastern Bering Sea in response to environmental variability across both warm and cold periods. Larvae were sampled in spring (May) during 5 cruises between 2002 and 2008 using oblique $60 \mathrm{~cm}$ bongo tows. Non-metric multidimensional scaling (NMDS) was used to quantify variability and reduce multi-species abundance data to major modes of species composition. Generalized additive models (GAMs) characterized spatial and temporal differences in assemblage structure as a function of environmental covariates. We identified a strong crossshelf gradient delineating slope and shelf assemblages, an influence of water masses from the Gulf of Alaska on species composition, and the importance of nearshore areas for larval fish. Species assemblages differed between warm and cold periods, and larval abundances were generally greater in warm years. High abundances of walleye pollock in warm years contributed most to differences in Unimak Pass, outer domain, and shelf areas (geographic areas in the study region defined based on bathymetry). Sebastes spp. contributed to differences over the slope with increased abundances in cold years. We propose that community-level patterns in larval fish composition may reflect speciesspecific responses to climate change and that early life stages may be primary indicators of environmental change.
\end{abstract}

KEY WORDS: Larval fish · Southeastern Bering Sea · Community structure · Walleye pollock · Theragra chalcogramma $\cdot$ Environmental variability

\section{INTRODUCTION}

Climate variability affects marine ecosystems through direct effects on ocean temperatures; an underlying warming trend (IPCC 2007) is therefore likely to affect commercial, recreational, and subsistence fisheries. Community-level consequences of environmental variability arise because species have different temperature tolerances (physiological optima and limits) and mobility to stay within their preferred thermal range (Pörtner et al. 2001). Populations or species with higher temperature optima will have a com- petitive advantage in warm conditions, resulting in species turnover and changes in community composition (e.g. Chavez \& Messié 2009). In addition to direct responses of fish and other organisms, temperature changes are modulated by simultaneous changes in food availability and predation pressure, which are more difficult to predict because they interact in nonlinear ways (Ciannelli et al. 2004).

Most previous studies have focused on temperature effects on adult demersal fish and shellfish communities (Brander et al. 2003, Perry et al. 2005, Mueter et al. 2007, Mueter \& Litzow 2008, Spencer 2008). Less work 
has been done to investigate changes in the pelagic community structure or early life stages of fishes (Duffy-Anderson et al. 2006, Brodeur et al. 2008, Doyle et al. 2009). The pelagic distribution of ichthyoplankton is related to the spawning locations of adult fish (Doyle et al. 2002). After spawning, larval drift is subject to advection of water masses (Lanksbury et al. 2005), which is strongly influenced by wind stress and varies interannually as a result of basin-scale climate variability. Transport pathways can lead to differential survival of larvae based on life history characteristics (Doyle et al. 2009), predator abundances (Hunt et al. 2002), or availability of suitable juvenile habitat (Wilderbuer et al. 2002). Understanding variability in ichthyoplankton assemblage structure may indicate ecosystem-level and/or species-specific responses to climate change.

The southeastern Bering Sea has experienced both warm and cold conditions (as defined in Hunt et al. 2002 , in press) in recent years, offering an opportunity to examine changes in larval fish community compositions. Underlying this variability is a long-term warming trend of approximately $0.1^{\circ} \mathrm{C}$ per decade, with the most pronounced increases occurring during summer months (F. Mueter unpubl. data). Historically, sea surface temperatures (SSTs) in the Bering Sea were cool in the early 20th century followed by a relatively warm period from 1925 to the mid- to late 1940s. Temperatures in the 1950s to early 1970 s were also cool, but increased after the 1976-77 regime shift (Hare \& Mantua 2000). The Bering Sea has been generally warmer following this regime shift, and the highest summer temperatures since the beginning of the last century were observed between 2002 and 2005. However, the most extensive ice cover and coldest water column temperatures since the early 1970s were observed from 2006 to at least the end of 2010. While water-column temperatures have been much lower recently, average SSTs over the shelf during late summer have stayed relatively high (Mueter et al. 2009).

The goal of this work is to quantify how spring larval fish assemblages respond to environmental variability, in particular temperature variability, and to examine what delineates community composition in the southeastern Bering Sea. Characterizing patterns in larval fish community composition for the waters north of the Alaska Peninsula is of particular interest because this region includes known spawning and nursery areas for a variety of ecologically and economically important groundfish species (Lanksbury et al. 2007, Bacheler et al. 2010). In addition, the influx of larvae advected through Unimak Pass from the Gulf of Alaska (e.g. northern rock sole Lepidopsetta polyxystra) (Lanksbury et al. 2007) may have important ecological consequences as these species interact with local populations.

\section{STUDY REGION}

The southeastern Bering Sea is characterized by a broad continental shelf ( $>500 \mathrm{~km}$ wide) with an average depth of only about $70 \mathrm{~m}$ and supports a highly productive ecosystem owing to on-shelf flow of nutrient-rich waters. From spring to early fall, persistent oceanographic fronts (Hunt \& Stabeno 2002) separate the shelf into 3 domains: the inner shelf domain (inside of the $50 \mathrm{~m}$ isobath), the middle domain (between 50 and $100 \mathrm{~m}$ isobaths), and the outer domain (between 100 and $200 \mathrm{~m}$ isobaths) (Iverson et al. 1979, Coachman 1986).

Predominant currents onto the southeastern Bering Sea shelf include the Alaska Coastal Current (ACC) that transports lower salinity waters from the Gulf of Alaska through Unimak Pass, and the Aleutian North Slope Current that brings higher salinity oceanic waters to the slope (Schumacher \& Stabeno 1998, Stabeno et al. 2006). Current trajectories over the shelf are generally northwestward with the Bering Slope Current flowing along the shelf break and ACC waters following either the 50 or $100 \mathrm{~m}$ isobath (Stabeno et al. 2001).

The ACC flows counterclockwise around the Gulf of Alaska and southwestward along the Alaskan Peninsula; it branches through Unimak Pass, which represents the major conduit of flow between the Gulf of Alaska and the Bering Sea shelf (Ladd et al. 2005). The volume of ACC water advected through Unimak Pass varies seasonally and interannually (Stabeno et al. 2002). Freshwater discharge into the Gulf of Alaska can be used as a proxy for the strength of the ACC and, presumably, flow through Unimak Pass (Weingartner et al. 2005). Average discharge in March for 2002 to 2005 was $9764 \mathrm{~m}^{3} \mathrm{~s}^{-1}$ versus $1872 \mathrm{~m}^{3} \mathrm{~s}^{-1}$ for 2006 to 2008 (T. Royer unpubl. data based on formulae in Royer 1982) suggesting greater flow through Unimak Pass in warm years. The direction of ACC waters entering the Bering Sea varies based on differences in forcing mechanisms (e.g. wind speed and direction) that affect water column structure and front formation. The onset and location of fronts affect water current trajectories (Kachel et al. 2002) and, therefore, transport pathways of larvae (Duffy-Anderson et al. 2006).

\section{MATERIALS AND METHODS}

Biological sampling. Data on spring larval fish assemblage structure were collected during 5 research cruises in the southeastern Bering Sea (Fig. 1) between 2002 and 2008 using $60 \mathrm{~cm}$ bongo nets fitted with either $335 \mu \mathrm{m}$ (2008) or $505 \mu \mathrm{m}$ (2002, 2003, 2005, 2006) mesh; previous research determined that abundances of collected larvae are comparable between the 
2 mesh sizes (Shima \& Bailey 1994, Boeing \& Duffy-Anderson 2008, DuffyAnderson et al. 2010). Cruises occurred in May of each year (Table 1). During all cruises, quantitative oblique tows were made to a maximum depth of $300 \mathrm{~m}$ (or to within $10 \mathrm{~m}$ of the substratum), allowing for vertically integrated estimates of larval fish abundance. The ship speed was monitored and adjusted (1.5 to 2.5 knots) throughout each tow to maintain a wire angle
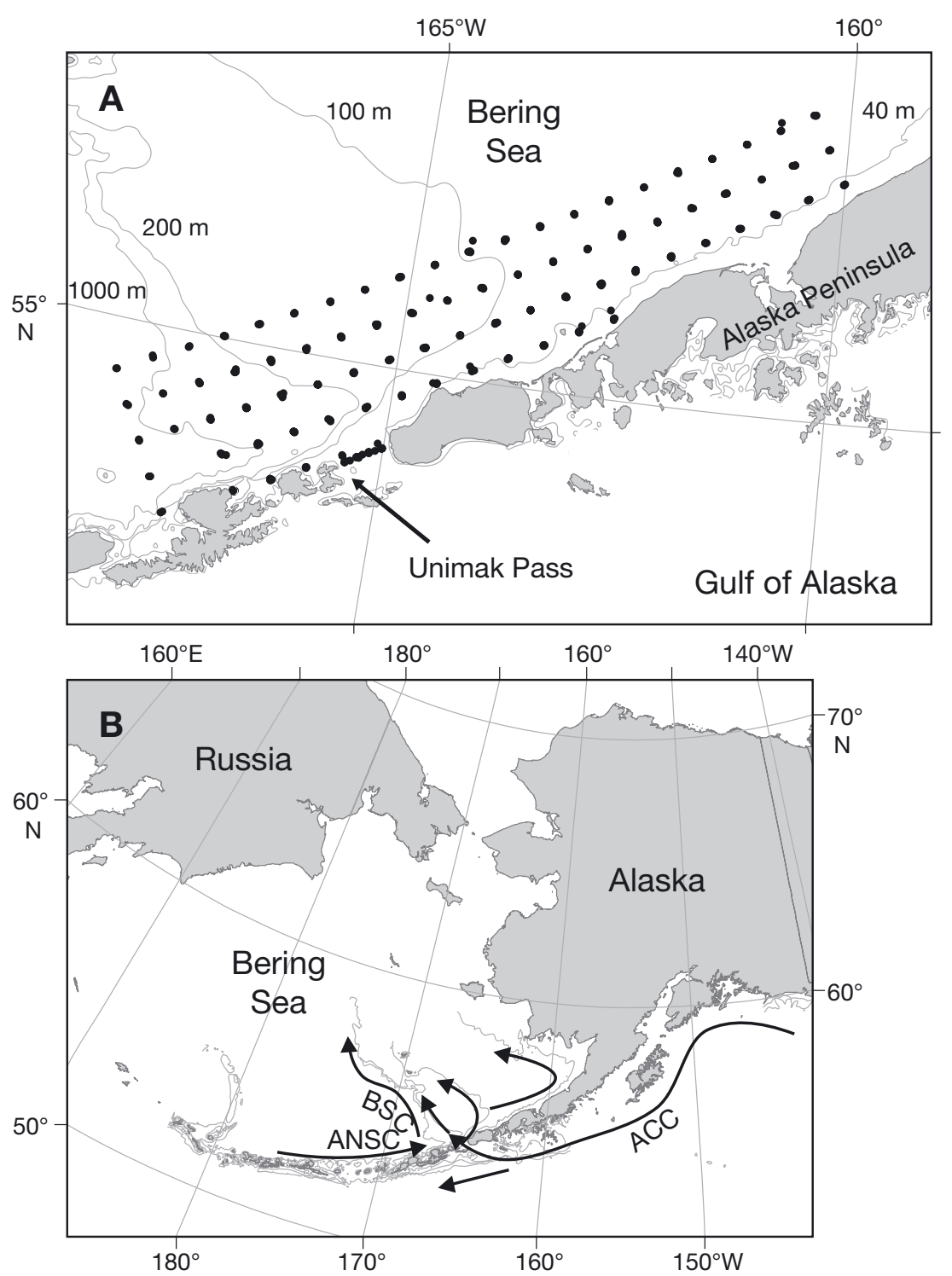

Fig. 1. (A) Study region showing the location of sampling stations $(\bullet)$. To investigate changes in larval fish assemblage structure over time, only those stations sampled in at least 2 yr were included in the analyses ('common stations'; see Table 1). Depth contours are shown for the 40,100, 200, and $1000 \mathrm{~m}$ isobaths. (B) Predominant currents in the study region include the Aleutian North Slope Current (ANSC), the Bering Slope Current (BSC), and the Alaska Coastal Current (ACC)
Table 1. Cruise name, year, temperature regime, and dates of cruises. The total number of stations sampled ('bongo tows') and the number of stations used in the analysis ('common stations') by year are shown

\begin{tabular}{|cccccc|}
\hline Cruise & Year & $\begin{array}{c}\text { Temperature } \\
\text { regime }\end{array}$ & Dates & $\begin{array}{c}\text { Bongo } \\
\text { tows }\end{array}$ & $\begin{array}{c}\text { Common } \\
\text { stations }\end{array}$ \\
\hline 3MF02 & 2002 & Warm & 13-21 May & 81 & 65 \\
4MF03 & 2003 & Warm & 18-24 May & 60 & 58 \\
5MF05 & 2005 & Warm & 10-20 May & 91 & 68 \\
3MF06 & 2006 & Cold & 9-18 May & 90 & 75 \\
3DY08 & 2008 & Cold & 13-21 May & 65 & 52 \\
& & & Total & $\mathbf{3 8 7}$ & $\mathbf{3 1 8}$ \\
\hline
\end{tabular}

of $45^{\circ}$ from the ship to the bongo net. The nets were equipped with a calibrated flow meter; therefore, catch rates were standardized to catch per unit effort (CPUE; number per $10 \mathrm{~m}^{2}$ ). Sampling occurred $24 \mathrm{~h}$ a day, and it was assumed that vertically integrated abundance estimates were not affected by diel vertical migrations. The geographic coverage of the sampling grid varied each year; to investigate changes in larval fish assemblage structure over time, only those stations sampled in at least $2 \mathrm{yr}$ were included in the analyses ('common stations') (Table 1, Fig. 1).

After retrieval of the bongo nets, all fish larvae were removed from the cod ends, and a volume displacement measurement of remaining zooplankton (including small gelatinous zooplankton; large jellyfish were removed so as not to bias the displacement volume) was taken as a coarse measure of zooplankton wet weight biomass and an index of overall production at each station (Napp et al. 2002, Coyle et al. 2008, 2011). All samples were preserved at sea in $5 \%$ buffered formalin seawater solution. Fish larvae were sorted, identified to the lowest possible taxonomic level, measured (mm standard length, SL), and enumerated at the Plankton Sorting and Identification Center in Szczecin, Poland. Identifications were verified at the Alaska Fisheries Science Center, NOAA (National Oceanic and Atmospheric Administration) in Seattle, Washington, USA.

Physical environment sampling. A Sea-Bird SBE 19 CTD was attached inline between the bongo nets and the wire terminus to provide real-time measurements of temperature, conductivity, 
and pressure over the towed path. An estimate of the water temperature within the study area each year was calculated by averaging the sampled water column temperature across all stations in a given year. Temperature and salinity measurements were averaged throughout the sampled water column at each station for comparison with the vertically integrated larval fish abundances to determine the characteristics of the water column when larvae were present. Larvae likely originated from different water masses (e.g. above and below the pycnocline), but any effect of averaging was consistent across the study region (Duffy-Anderson et al. 2006). Temperature and salinity were also averaged within the top $20 \mathrm{~m}$ (surface layer) to visualize and identify water mass characteristics by geographic areas. Water column profiles varied from well-mixed nearshore stations to more stratified offshore stations. Surface water characteristics best captured broad differences by area and provided a reasonable metric to track the less-saline (i.e. less dense) ACC water through Unimak Pass and subsequent mixing on the shelf.

Four distinct geographic areas were examined for the analyses, and stations were grouped as follows: Unimak Pass, slope (outside of $200 \mathrm{~m}$ isobath), outer domain (between 100 and $200 \mathrm{~m}$ isobaths), and shelf (within $100 \mathrm{~m}$ isobath). Very few stations were sampled within the inner domain (inside of $50 \mathrm{~m}$ ) therefore these were combined with the middle domain (between 50 and $100 \mathrm{~m}$ ) stations and comprised the shelf area. Surface (top $20 \mathrm{~m}$ ) measurements of temperature and salinity distinguished unique water masses within each geographic area. Unimak Pass and the outer domain water masses had intermediate salinities, with Unimak Pass stations having relatively colder temperatures. Slope waters had the highest salinities and warmest temperatures while shelf waters had lower salinities and colder water temperatures (Fig. 2).

Community analyses. To quantify variability in species composition over time and space, we used nonmetric multidimensional scaling (NMDS) to reduce multi-species abundance data to their major modes of variability (PRIMER 6, v6.1.11) (Clarke \& Gorley 2006). NMDS allowed us to detect patterns in the biological data first and then interpret those patterns in relation to the environmental data (Field et al. 1982) using generalized additive models (GAMs). NMDS is also more robust to violations of assumptions than other methods (e.g. detrended correspondence analysis or principle components analysis) (Minchin 1987). Stations at which no larval fish were caught $(n=8)$ and rare species, defined as those present at less than $5 \%$ of the stations across all years, were removed from the analyses. Rare species likely do not contribute to broad- scale temporal and spatial patterns (Duffy-Anderson et al. 2006), therefore our approach allowed for detection of substantial shifts in species composition between years.

Larval fish abundance data were highly rightskewed, therefore a 4 th root transformation $\left(\mathrm{CPUE}^{0.25}\right.$ ) was used to reduce the influence of samples with very high abundances. Transformed data were standardized to species maxima (i.e. each value was divided by the maximum $\mathrm{CPUE}^{0.25}$ value for the corresponding species) to give equal weight to all species, regardless of their average numerical abundance (Field et al. 1982). Bray-Curtis similarity matrices were then computed to examine differences in assemblage structure among (1) individual stations and (2) by geographic area based on larval fish composition, followed by ordinations using NMDS to visualize similarities in species composition among stations or areas. The NMDS algorithm attempts to arrange samples (either stations or areas) such that pairwise distances in the ordination plot match Bray-Curtis similarities as closely as possible; thus, samples closer together in the ordination plot have a more similar species composition than samples farther apart. The final configuration of samples was determined by minimizing Kruskal's stress statistic (Kruskal 1964), and the number of dimensions for the final ordinations was chosen as the smallest number of dimensions that achieved a stress of no more than 0.2 . A stress of 0.1 or lower is considered a good fit (Kruskal 1964), and we defined a stress of less than 0.2 as acceptable.

NMDS by station: The final station-by-species matrix included 318 stations (Table 1) and 31 prevalent species (or species complexes) (see Table 2). The ordination axes in the NMDS plot, consisting of dimensionless values or scores for each station, were used as the response variable for modeling differences in assemblage structure in space and as a function of environmental covariates using GAMs. Spearman rank correlations were used to identify those species whose abundances were most strongly correlated (positively or negatively) with the axis scores and which therefore contributed most to the observed patterns of species composition. Only species for which the absolute correlation with a given ordination axis was equal to or larger than 0.4 were further examined.

A GAM approach was used for modeling species composition to avoid pre-specifying a functional relationship between the response and predictor variables. GAMs quantify the relationship between a set of predictors and the response through non-parametric smooth functions of the predictor variables (e.g. a smooth spatial surface can be fit as a function of latitude and longitude). The optimum amount of smoothing was chosen through a cross-validation approach as 

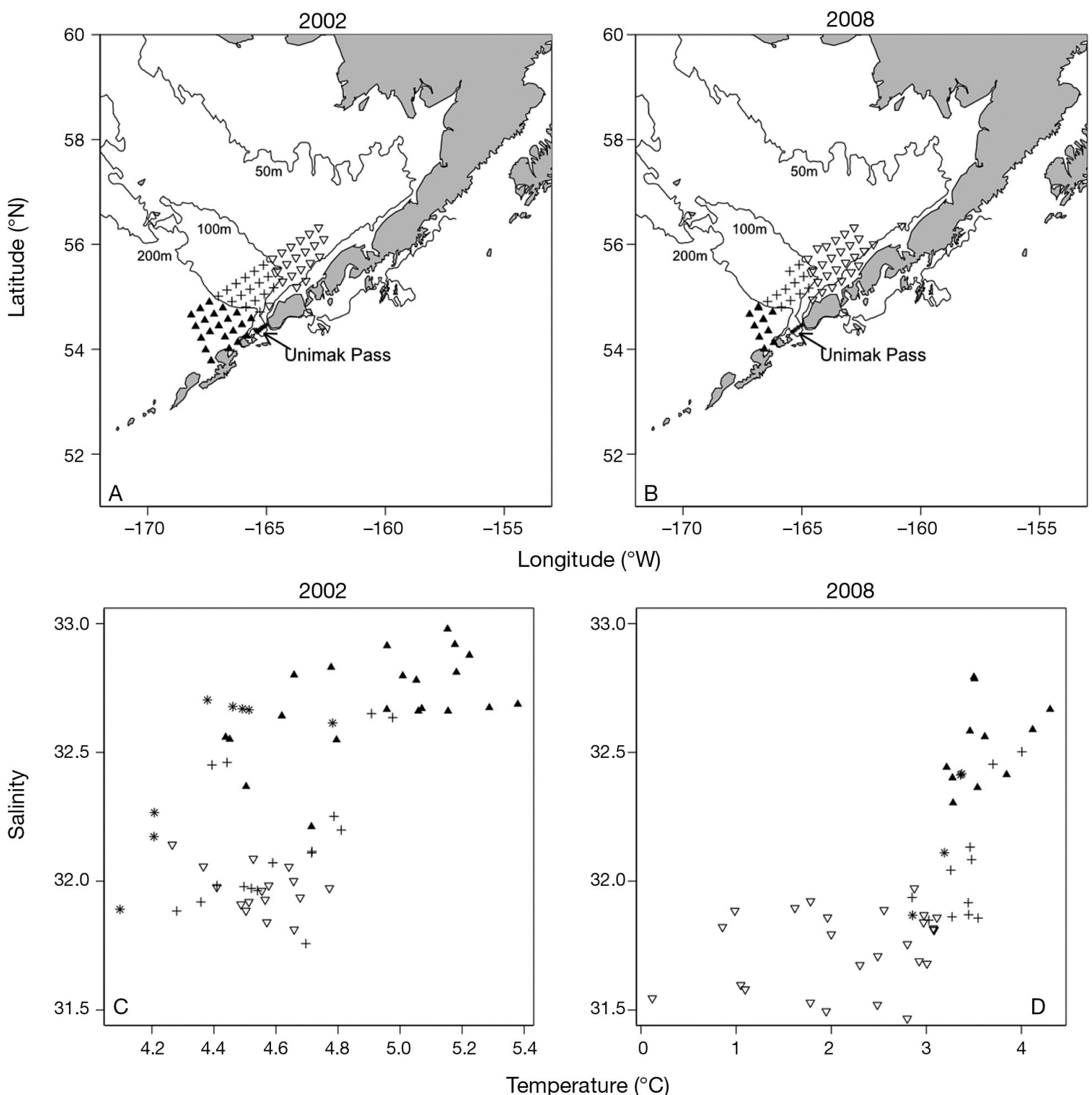

Fig. 2. Stations sampled in (A) 2002 and (B) 2008, and corresponding temperature and salinity plots (averaged across the top $20 \mathrm{~m}$ ) for (C) 2002 and (D) 2008. Samples were collected in 4 geographic areas based on bathymetry: Unimak Pass (*), slope (ム outside of $200 \mathrm{~m}$ isobath), outer domain (+; between 100 and $200 \mathrm{~m}$ isobaths), and shelf $(\nabla ;$ within $100 \mathrm{~m}$ isobath). $2002 \mathrm{was}$ a warm year showing increased mixing of water masses from Unimak Pass to the shelf; 2008 was a cold year with greater distinction of water masses. Note the difference in the $x$-axis scale in C and D

implemented in the R package 'mgcv' (Wood 2006). Appropriate (biologically meaningful) covariates (year, temperature, salinity, zooplankton displacement volume, latitude, and longitude) were selected to explain variability in larval fish assemblage structure. Station depth (bathymetry) is strongly confounded with the spatial term (latitude and longitude), and the estimated spatial surface captures any effects of location whether related to bathymetry, distance from shore, or other variables. Therefore, we did not include station depth as a covariate in the model.
The full model included a categorical year term to allow for differences in the average response between years (subscript $t$ denotes different years), a smooth function $(f)$ of temperature and salinity to allow for possible interactions, a smooth function of zooplankton displacement volume, and a smooth spatial surface (interaction term for latitude and longitude):

Axis $1=$ Year $_{t}+f_{1}$ (Temperature, Salinity $)+$

$f_{2}$ (Zooplankton displacement volume) + 
Alternative models were considered that included separate smooth terms for temperature and salinity or eliminated one or more variables from the model (e.g. no zooplankton displacement volume term). Based on Akaike's Information Criterion (AIC) (Akaike 1973, Burnham \& Anderson 2002) and the amount of variability explained by each model (adjusted $\mathrm{R}^{2}$ values), a best fit model was selected for characterizing the estimated effects of environmental variability on species composition for each axis.

NMDS by geographic area: We compared species composition by geographic area by averaging the CPUE for each species across all stations within a given area, which resulted in an area-by-species matrix that included 20 year-area combinations $(\mathrm{n}=5$ years; $\mathrm{n}=4$ areas) and 31 species. The PRIMER routine MVDISP, which measured the relative dispersion of yearly values within each area, was used to compare the variability in species composition by area across the study period. To examine differences in species composition between the warm period (years 2002, 2003, and 2005) and cold period (years 2006 and 2008), a 1-way analysis of similarity (ANOSIM) tested for pairwise differences between each area-period combination. Separate ANOSIM tests were performed for each area to further test whether species compositions were significantly different between warm and cold periods. A SIMPER (similarity percentages) analysis was then performed using the full station-by-species matrix to determine the contribution of individual species responsible for the dissimilarity between areas and periods.

\section{RESULTS}

\section{Biological sampling}

A total of 31 species or species complexes (e.g. Sebastes spp.) representing 14 different families were collected during 5 cruises over the 7 yr sampling period and were included in the community analyses. Walleye pollock Theragra chalcogramma was numerically the most abundant species in the assemblage (66\% of total catch), followed by Pacific sand lance Ammodytes hexapterus, rockfishes Sebastes spp., northern rock sole, and Pacific cod Gadus macrocephalus (Table 2). Individual species abundances varied interannually; for example, walleye pollock comprised a maximum of $85 \%$ of the total catch in 2002 to a minimum of $29 \%$ in 2006 (Fig. 3). Fish larvae were generally more abundant in the warm years than in the cold years, especially flathead sole Hippoglossoides elassodon, northern rock sole, and Pacific sand lance. Rare species, though not included in the analyses,

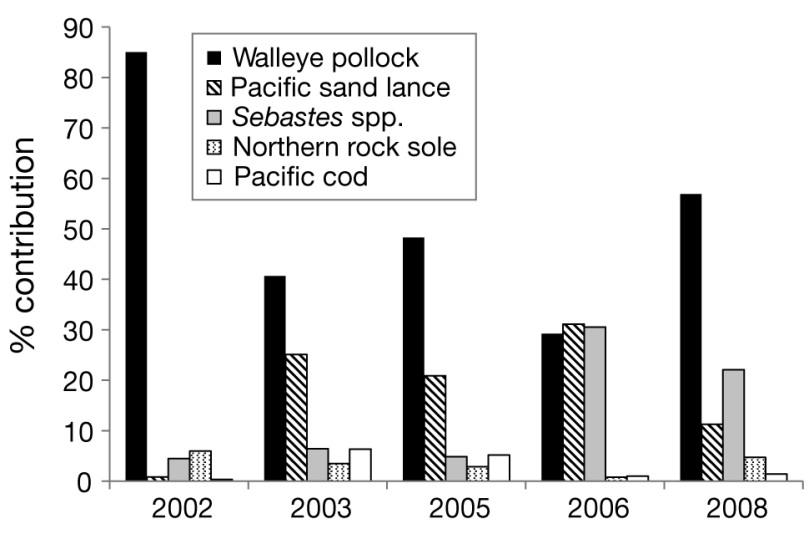

Fig. 3. Percent contribution to total catch (based on catch per unit effort) of the 5 overall most abundant species by year. The most abundant species were walleye pollock Theragra chalcogramma, Pacific sand lance Ammodytes hexapterus, Sebastes spp., northern rock sole Lepidopsetta polyxystra, and Pacific cod Gadus macrocephalus

were sampled in either warm years (e.g. high cockscomb Anoplarchus purpurescens and Greenland halibut Reinhardtius hippoglossoides) or cold years (e.g. Arctic cod Boreogadus saida).

\section{Physical environment sampling}

The average water column temperature varied considerably between the warmer years of 2002, 2003, and 2005 (3.86, 4.75, and $4.16^{\circ} \mathrm{C}$, respectively) and the colder years of 2006 and $2008\left(3.39\right.$ and $2.0^{\circ} \mathrm{C}$, respectively). This provided an environmental continuum against which to investigate changes in larval fish species composition. Water mass characteristics were unique at slope, outer domain, and shelf stations in cold years (Fig. 2D), but the outer domain and shelf waters were not as clearly separated in warm years (Fig. 2C). Unimak Pass stations generally displayed similar characteristics to outer domain waters; however, in 2002 and 2005, stations on the east side of Unimak Pass displayed characteristics of shelf waters, whereas stations on the west side of Unimak Pass were more similar to slope waters based on differences in salinity, indicating flow in both directions through Unimak Pass.

\section{Community analyses}

NMDS by station. The ordination of individual stations (Fig. 4) condensed information on the abundance of each species and afforded both community-level and species-specific gradients to be described across the study area. GAMs illustrated 3 patterns in species composition that captured important habitat attributes 
Table 2. Percent of total catch (based on number per $10 \mathrm{~m}^{2}$ ) for species (or species complexes) observed in greater than $5 \%$ of stations across the study period 2002 to 2008

\begin{tabular}{|c|c|c|c|}
\hline Taxon & Family & Common name & $\%$ Total catch \\
\hline Theragra chalcogramma & Gadidae & Walleye pollock & 66.44 \\
\hline Ammodytes hexapterus & Ammodytidae & Pacific sand lance & 10.72 \\
\hline Sebastes spp. & Scorpaenidae & Rockfishes & 8.86 \\
\hline Lepidopsetta polyxystra & Pleuronectidae & Northern rock sole & 4.55 \\
\hline Gadus macrocephalus & Gadidae & Pacific cod & 1.86 \\
\hline Hippoglossoides elassodon & Pleuronectidae & Flathead sole & 1.53 \\
\hline Platichthys stellatus & Pleuronectidae & Starry flounder & 1.32 \\
\hline Bathymaster spp. & Bathymasteridae & & 0.95 \\
\hline Unidentified Gadidae & Gadidae & & 0.86 \\
\hline Pleuronectes quadrituberculatus & Pleuronectidae & Alaska plaice & 0.72 \\
\hline Atheresthes spp. & Pleuronectidae & & 0.29 \\
\hline Poroclinus rothrocki & Stichaeidae & Whitebarred prickleback & 0.26 \\
\hline Bathylagus pacificus & Bathylagidae & Pacific blacksmelt & 0.17 \\
\hline Icelus spp. & Cottidae & & 0.17 \\
\hline Liparis spp. & Liparidae & & 0.13 \\
\hline Myохосерhalus spp. & Cottidae & & 0.13 \\
\hline Anoplarchus insignis & Stichaeidae & Slender cockscomb & 0.11 \\
\hline Cryptacanthodes aleutensis & Cryptacanthodidae & Dwarf wrymouth & 0.10 \\
\hline Hippoglossus stenolepis & Pleuronectidae & Pacific halibut & 0.10 \\
\hline Leuroglossus schmidti & Bathylagidae & Northern smoothtongue & 0.10 \\
\hline Anoplarchus spp. & Stichaeidae & & 0.09 \\
\hline Lepidopsetta bilineata & Pleuronectidae & Southern rock sole & 0.09 \\
\hline Stenobrachius leucopsarus & Myctophidae & Northern lampfish & 0.08 \\
\hline Icelinus spp. & Cottidae & & 0.07 \\
\hline Hemilepidotus hemilepidotus & Cottidae & Red Irish lord & 0.05 \\
\hline Hexagrammos decagrammus & Hexagrammidae & Kelp greenling & 0.05 \\
\hline Bathyagonus alascanus & Agonidae & Gray starsnout & 0.04 \\
\hline Bathyagonus infraspinatus & Agonidae & Spinycheek starsnout & 0.04 \\
\hline Podothecus acipenserinus & Agonidae & Sturgeon poacher & 0.04 \\
\hline Artedius harringtoni & Cottidae & Scalyhead sculpin & 0.03 \\
\hline Psychrolutes paradoxus & Psychrolutidae & Tadpole sculpin & 0.03 \\
\hline
\end{tabular}

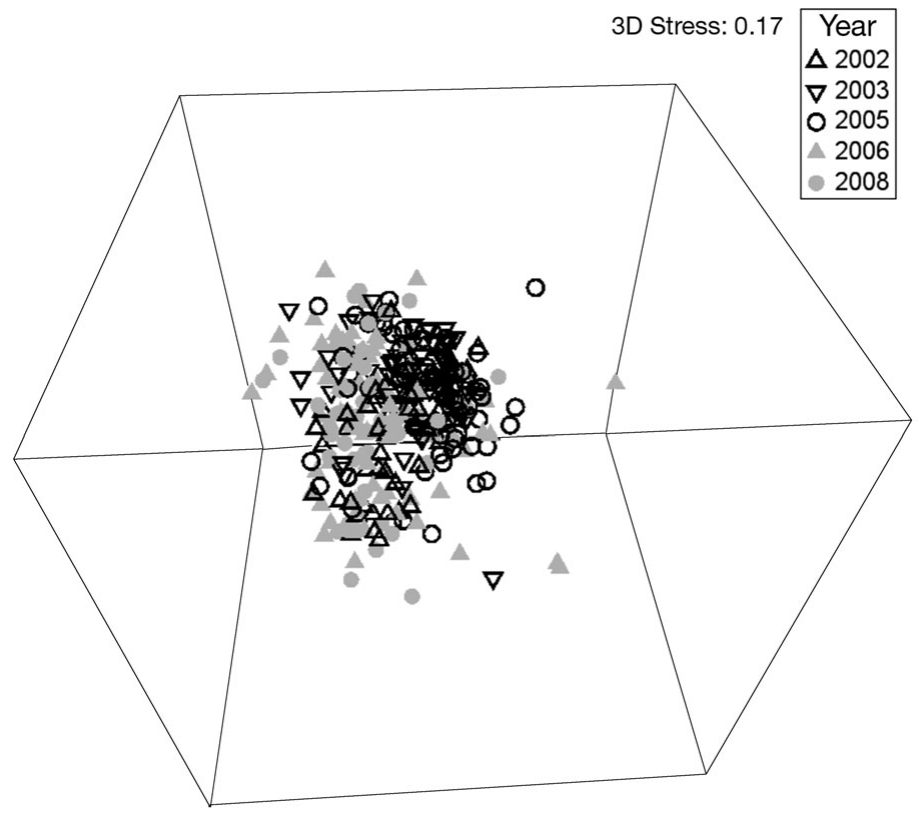

Fig. 4. Non-metric multidimensional scaling (NMDS) ordination, based on a Bray-Curtis similarity matrix, depicting the relative similarity in species composition among individual stations sampled across $5 \mathrm{yr}$. Data were 4 th root transformed and standardized to species maximum for larval fish distributions, as described below. Spearman rank correlations with the NMDS axis scores showed which individual species contributed most to the observed gradients. The first axis captured the greatest amount of variability in species composition, which was corroborated by strong species correlations, both positive and negative. Several species were strongly positively correlated with the second and third axes; however, no species were strongly negatively correlated with these axes (Table 3 ).

Generalized additive models: Axis 1: The first axis described a gradient between a slope assemblage (species positively correlated with Axis 1) and a shelf assemblage (negatively correlated with Axis 1) that was resilient to interannual differences in species abundances (Fig. 5A). The slope assemblage was characterized by Sebastes spp. and Atheresthes spp., as well as several deeper water species including Pacific blacksmelt Bathylagus pacificus. In contrast, the shelf assemblage was characterized by Alaska plaice, Pacific sand lance, walleye pollock, and northern rock sole (Table 3). 
Table 3. Spearman rank correlations for the 3 axes (dimensions) interpreted from the non-metric multidimensional scaling (NMDS) ordination by station. Only those species with correlations $\geq 0.4$ are shown

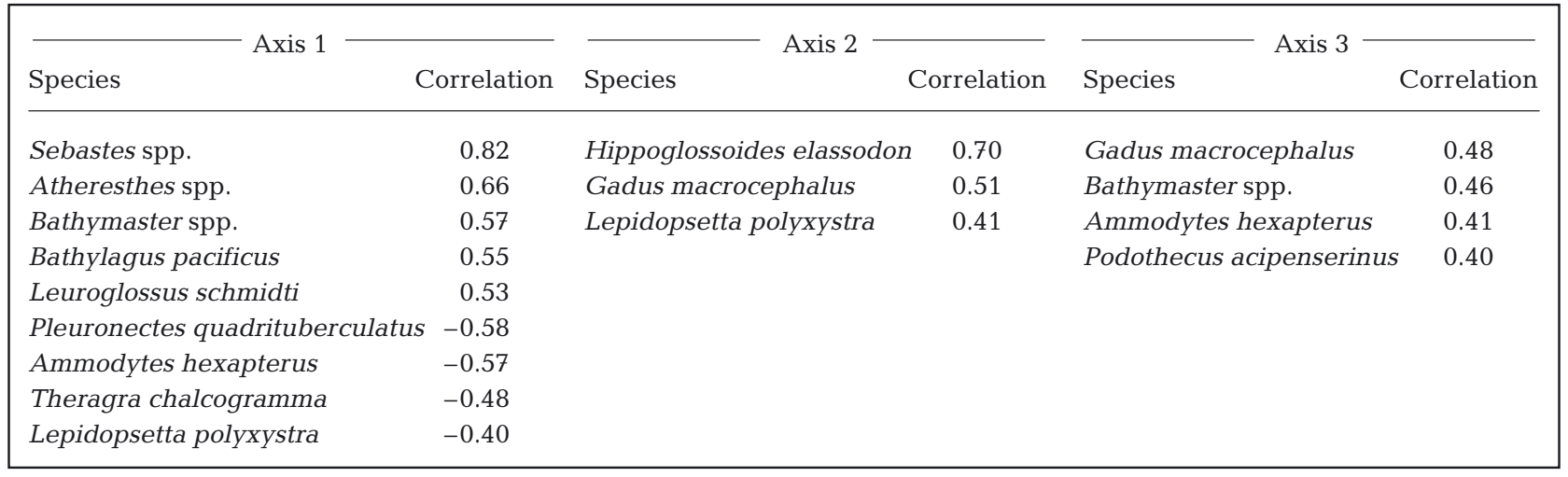

The best model for Axis 1 scores was described as:

$$
\begin{gathered}
\text { Axis } 1 \sim \text { Year }_{t}+f(\text { Temperature, Salinity })+ \\
f(\text { Latitude, Longitude })
\end{gathered}
$$

and included a significant categorical year term denoting a difference in the average value of the response among years, a significant smooth term of temperature and salinity, and a smooth spatial term (latitude and longitude) (Table 4). Although temperature and salinity were confounded with the spatial term, the latter largely captured residual variability not explained by either temperature or salinity. Zooplankton displacement volume was not significant in the full model described by Eq. (1) and was dropped from the best model. The model explained a significant proportion of the variability in species composition along the first axis (adjusted $\mathrm{R}^{2}=0.865 ; \mathrm{n}=318$ ).

Both temperature and salinity had a strong influence on species composition (Fig. 5B). The slope assemblage (positive correlations) was more common at higher temperatures and at higher salinities, while the shelf assemblage (negative correlations) was found at lower temperatures and salinities, corroborating the cross-shelf spatial pattern described above. In addition, we found significant variability in species composition among years (Fig. 5C) that was not explained by local water mass characteristics or spatial patterns. Species abundances were generally higher in warm years, driven by shelf species such as Pacific sand lance, flathead sole, and northern rock sole.

Axis 2: The second axis identified a plume of similar species composition originating in Unimak Pass and extending onto the shelf. Fig. 6A shows the average spatial pattern across all years, though the spatial extent of the plume varied between years. Species strongly correlated with this plume of water included flathead sole, Pacific cod, and northern rock sole (Table 3).
The best model for Axis 2 was described as:

$$
\begin{gathered}
\text { Axis } 2 \sim f(\text { Temperature, Salinity })+ \\
f(\text { Latitude, Longitude })
\end{gathered}
$$

and included a significant smooth term of temperature and salinity and a smooth spatial term (Table 4), however the year and zooplankton displacement volume terms were not significant. The model explained additional variability in species composition along the second axis of the NMDS ordination (adjusted $\mathrm{R}^{2}=0.423$; $\mathrm{n}=318$ ).

The water mass associated with the plume of species originating from the Unimak Pass region had warmer temperatures and lower salinities than surrounding waters (Fig. 6B). The ACC carries lower salinity waters from the Gulf of Alaska through Unimak Pass (Stabeno et al. 2002) and may have influenced the spatial distribution (i.e. plume) of species assemblages. After accounting for the effects of temperature and salinity, as well as the spatial pattern, there was no significant effect of year in Axis 2 scores, suggesting that interannual variability in species compositions was fully accounted for by interannual differences in water mass characteristics.

Axis 3: The third axis delineated species that were associated with nearshore habitats in waters north of the Alaska Peninsula (Fig. 7A). Species strongly positively correlated with Axis 3 included Pacific cod, Pacific sand lance, and sturgeon poacher Podothecus acipenserinus (Table 3).

The best model for Axis 3 was described as:

$$
\begin{gathered}
\text { Axis } 3 \sim f(\text { Temperature, Salinity })+ \\
f(\text { Latitude, Longitude })
\end{gathered}
$$

and included a significant smooth term of temperature and salinity and a smooth spatial term (latitude and longitude) (Table 4), whereas the year and zooplankton displacement volume terms were not significant. 

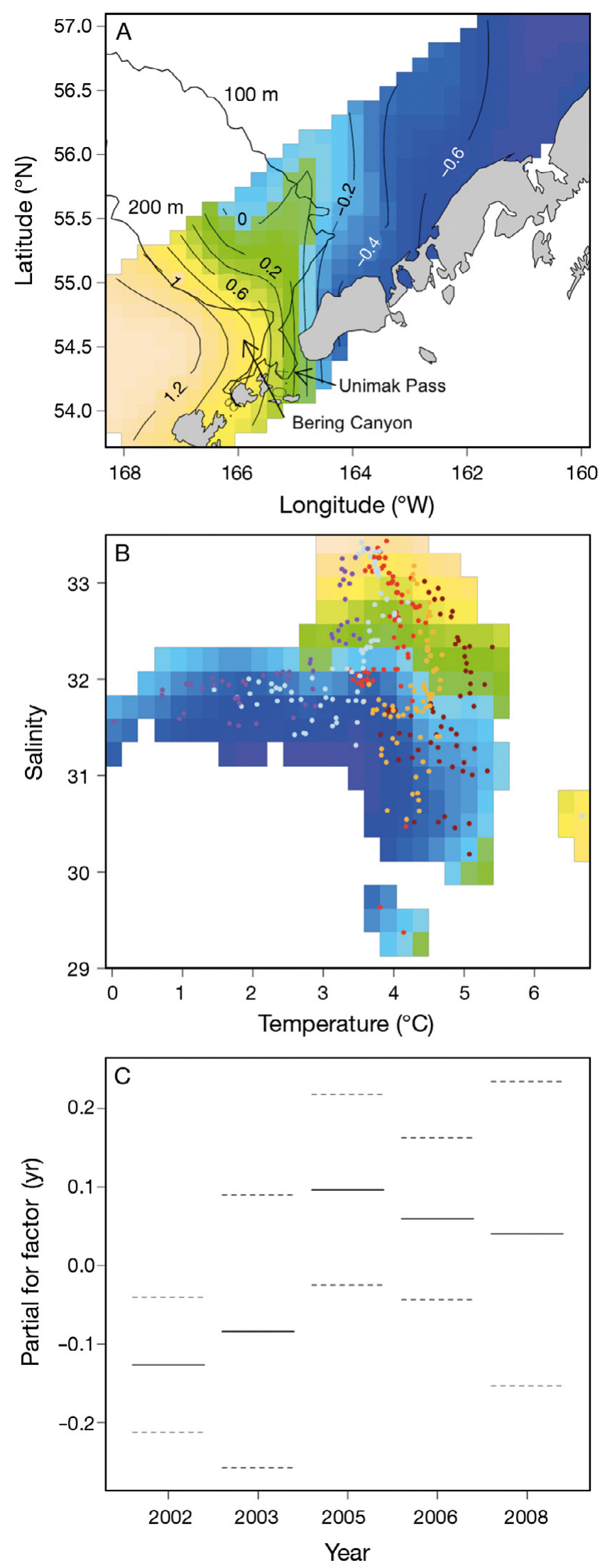

The model explained additional variability in species composition along the third axis (adjusted $\mathrm{R}^{2}=0.458$; $\mathrm{n}=318)$.

Temperature and salinity helped to distinguish the spatial pattern. Nearshore waters had warmer temperatures and lower salinities, whereas offshore waters had cooler temperatures and higher salinities (Fig. 7B). The nearshore species assemblage may reflect spawning habitat preferences of the adult stages.

NMDS by geographic area. The ordination by area (Fig. 8) allowed detection of changes in species composition across broader geographic areas by year. The ordination showed a clear gradient in species assem-

Table 4. Model terms with corresponding significance values for each axis in the generalized additive model (GAM) analyses. Temp: temperature; Sal: salinity; Lat: latitude; Long: longitude; Year $_{t}$ : year

\begin{tabular}{|c|c|c|c|c|c|}
\hline Axis & Term & df & $F$ & $\mathrm{p}$ & Adjusted $\mathrm{R}^{2}$ \\
\hline \multirow[t]{4}{*}{1} & & & & & \multirow[t]{4}{*}{0.865} \\
\hline & Year $_{t}$ & 4 & 6.952 & $<0.001$ & \\
\hline & Temp $\times$ Sal & 16.16 & 8.851 & $<0.001$ & \\
\hline & Lat $\times$ Long & 6.59 & 5.778 & $<0.001$ & \\
\hline \multirow[t]{3}{*}{2} & & & & & \multirow[t]{3}{*}{0.423} \\
\hline & Temp $\times$ Sal & 11.79 & 8.28 & $<0.001$ & \\
\hline & Lat $\times$ Long & 13.92 & 4.531 & $<0.001$ & \\
\hline \multirow[t]{2}{*}{3} & Temn $\times$ Sal & 1094 & 2815 & 0,0017 & \multirow{2}{*}{0.458} \\
\hline & Lat $\times$ Long & 17.27 & 8.281 & $<0.001$ & \\
\hline
\end{tabular}

Fig. 5. (A) Predicted spatial gradient of species composition as indicated by Axis 1 scores from non-metric multidimensional scaling (NMDS) ordination of species-by-station matrix, based on the generalized additive model (GAM) described by Eq. (2). The spatial surface was estimated as a smooth term of latitude and longitude; other covariates were fixed at their mean values. Species composition is predicted to be similar along contours; changes in species composition occur when moving across contours (color gradient). Spearman rank correlations of species positively or negatively correlated with these values were used to determine the main species of the slope versus shelf assemblage, respectively. Depth contours are shown for the 100 and $200 \mathrm{~m}$ isobaths. (B) Predicted measure of species composition (Axis 1 scores from NMDS ordination) as a smooth function of temperature and salinity based on the GAM described by Eq. (2). Stations with salinities less than $29(\mathrm{n}=3)$ were removed for better visualization of the relative effects of temperature and salinity. Cool colors correspond to the shelf habitat and negative species correlations; warm colors correspond to the slope habitat and positive species correlations (see A). Years are distinguished as follows: $2002=$ red, $2003=$ brown, 2005 = orange, 2006 = light blue, 2008 = purple. (C) Estimated differences in species composition among years (Axis 1 scores from NMDS ordination) based on the GAM described by Eq. (2). Solid lines reflect the partial response of Axis 1 scores, on a normalized scale, when all other covariates are fixed at their mean values. Dashed lines denote $95 \%$ confidence intervals 

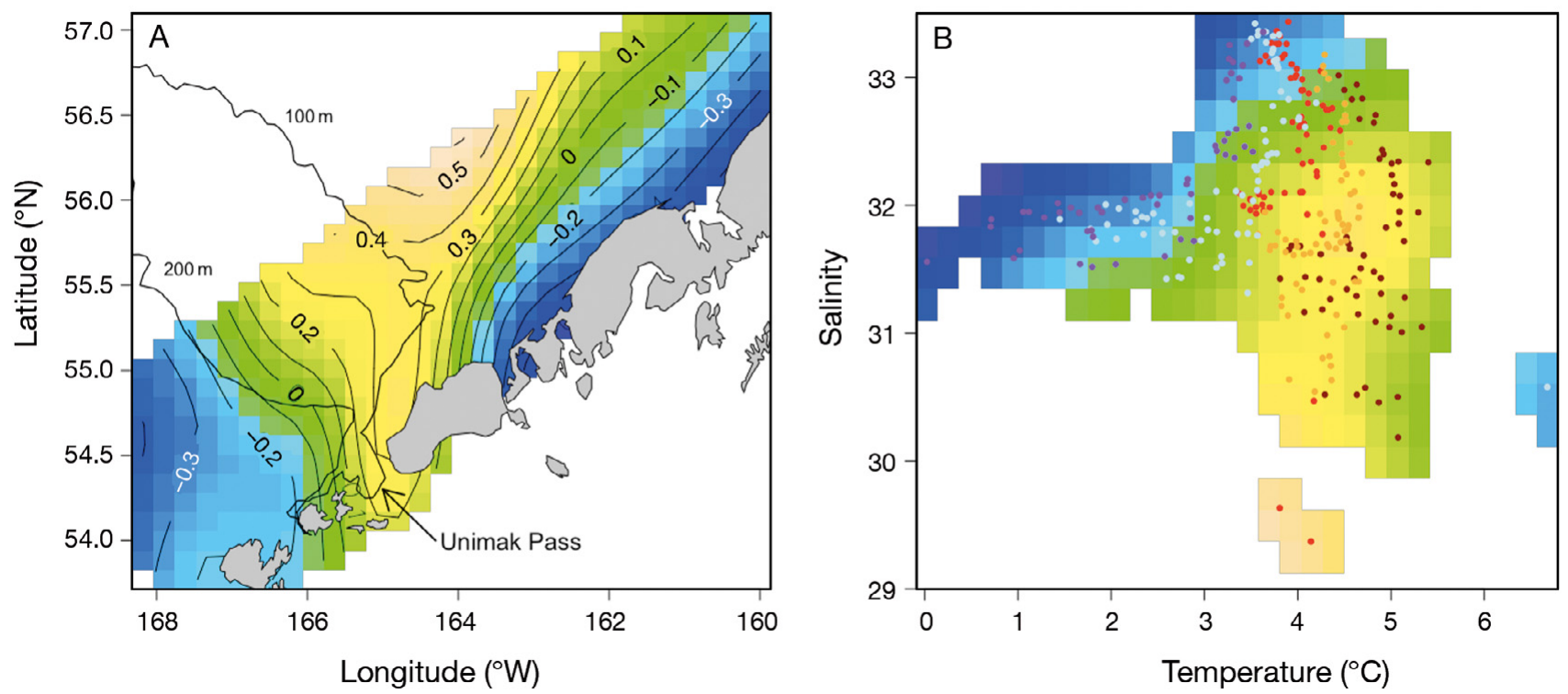

Fig. 6. (A) Predicted spatial gradient of species composition as indicated by Axis 2 scores from non-metric multidimensional scaling (NMDS) ordination of species-by-station matrix, based on the generalized additive model (GAM) described by Eq. (3). Spearman rank correlations of species positively correlated with these values were used to determine the main species of the Alaska Coastal Current assemblage. (B) Predicted measure of species composition (Axis 2 scores from NMDS ordination) as a smooth function of temperature and salinity based on the GAM described by Eq. (3). Warm colors correspond to the Alaska Coastal Current waters and positive species correlations (see A). See Fig. 5 for additional description.
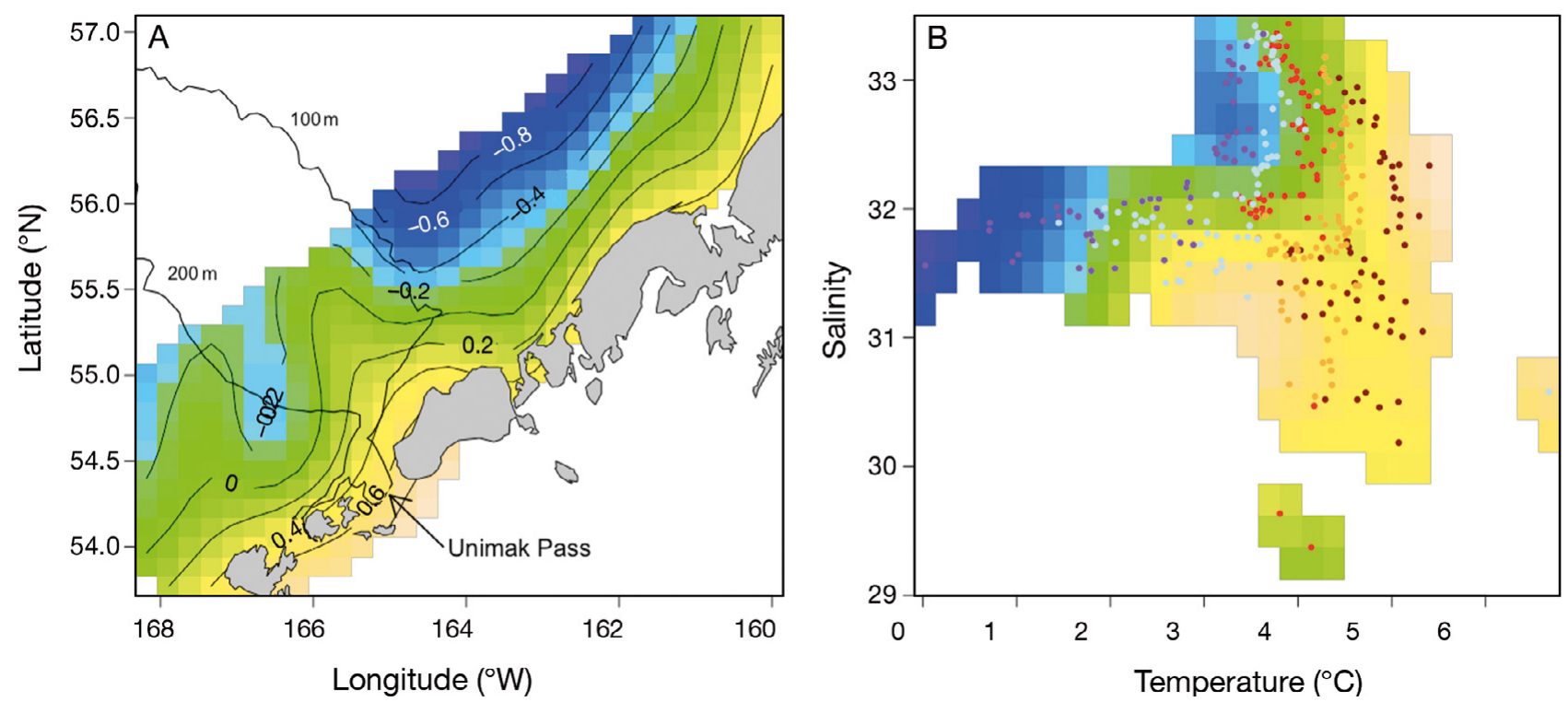

Fig. 7. (A) Predicted spatial gradient of species composition as indicated by Axis 3 scores from non-metric multidimensional scaling (NMDS) ordination of species-by-station matrix, based on the generalized additive model (GAM) described by Eq. (4) Spearman rank correlations of species positively correlated with these values were used to determine the main species of the nearshore assemblage. (B) Predicted measure of species composition (Axis 3 scores from NMDS ordination) as a smooth function of temperature and salinity based on the GAM described by Eq. (4). Warm colors correspond to the nearshore habitat and positive species correlations (see A). See Fig. 5 for additional description

blages from the slope to the shelf. Unimak Pass assemblages were more similar to outer domain assemblages in warm years, but less so in cold years. Species compositions were more variable between warm and cold periods for Unimak Pass, the outer domain, and shelf areas. In contrast, the slope assemblage was less variable across the study period based on average rank dissimilarity (MVDISP; Unimak Pass $=1.44$; slope $=$ 0.63 ; outer domain $=0.8$; shelf $=1.13$ ) . Pairwise comparisons showed the highest dissimilarity among years 


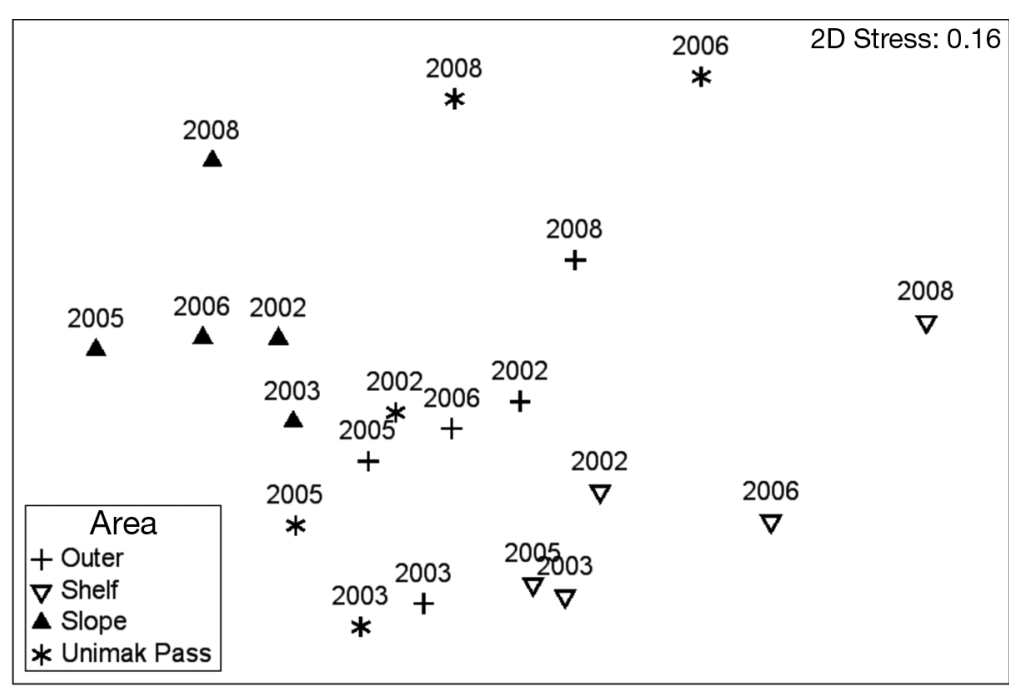

Fig. 8. Non-metric multidimensional scaling (NMDS) ordination, based on a Bray-Curtis similarity matrix, depicting the relative similarity in species composition among geographic areas by year. Outer domain: between 100 and $200 \mathrm{~m}$ isobaths; Shelf: within $100 \mathrm{~m}$ isobath; Slope: outside of $200 \mathrm{~m}$ isobath; Unimak Pass (see Fig. 1). Data were 4th root transformed and standardized to species maximum

for Unimak Pass and the lowest dissimilarity for slope stations (Index of Multivariate Dispersion [IMD] = -0.76 , where -1 would indicate maximum difference).

All unique area-by-period combinations showed significant differences in species assemblages (ANOSIM; $\mathrm{p}<0.05)$, except slope assemblages between warm and cold periods $(p=0.08)$ and between Unimak Pass and outer domain assemblages in warm $(p=0.19)$ and cold $(p=0.1)$ periods. Within each area, species compositions were significantly different between warm and cold periods ( $p<0.05$ for all), though the difference on the slope was only weakly significant $(p=$
0.041). SIMPER then identified which individual species contributed most to assemblage differences between the warm and cold periods for each area. The average abundance of Sebastes spp. contributed most to differences in the slope assemblage, with more Sebastes spp. in cold years. The abundance of walleye pollock contributed most to assemblage differences in Unimak Pass, outer domain, and shelf areas with greater abundances of walleye pollock during the warm period (Table 5).

\section{DISCUSSION}

Larval fish community composition in the southeastern Bering Sea was delineated by strong spatial patterns related to differences in water column temperature and/or salinity. Interannual differences in assemblage composition were attributed to species-specific responses to warm or cold conditions. Larval abundances were generally higher in warm years with high abundances of walleye pollock contributing most to differences in Unimak Pass, outer domain, and shelf areas between warm and cold periods. Assemblages over the slope were less variable between years and may be somewhat insulated from interannual variability. The slope assemblage was consistently dominated by Sebastes spp. with increased abundances in cold years. Therefore, community-level patterns in larval fish composition may reflect species-specific responses to environmental variability.

Table 5. Results from the PRIMER routine SIMPER used to identify differences in relative species composition based on geographic area and period using the full station-by-species matrix. The average abundance (catch per unit effort, CPUE, number per $10 \mathrm{~m}^{2}$ ) is shown for species that account for a significant amount of observed dissimilarity between periods; species' abundances in bold account for approximately $60 \%$ of dissimilarity for the given area. For each geographic area separately, a 1-way analysis of similarity (ANOSIM) was used to test for significant differences in species composition between warm and cold periods using the Bray-Curtis similarity matrix; the ANOSIM test statistic (R) and significance (p-value) are shown

\begin{tabular}{|c|c|c|c|c|c|c|c|c|}
\hline $\begin{array}{l}\text { Geographic } \\
\text { area }\end{array}$ & Period & $\begin{array}{c}\text { Theragra } \\
\text { chalcogramma }\end{array}$ & $\begin{array}{l}\text { Sebastes } \\
\text { spp. }\end{array}$ & $\begin{array}{l}\text { Ammodytes } \\
\text { hexapterus }\end{array}$ & $\begin{array}{c}\text { Bathymaster } \\
\text { spp. }\end{array}$ & $\begin{array}{c}\text { Gadus } \\
\text { macrocephalus }\end{array}$ & $\mathrm{R}$ & $\mathrm{p}$ \\
\hline Unimak Pass & $\begin{array}{l}\text { Warm } \\
\text { Cold }\end{array}$ & $\begin{array}{r}270.8 \\
8.1\end{array}$ & $\begin{array}{l}46.9 \\
73.1\end{array}$ & $\begin{array}{l}66.5 \\
19.6\end{array}$ & $\begin{array}{r}49.1 \\
2.1\end{array}$ & $\begin{array}{r}218.8 \\
24.5\end{array}$ & 0.45 & 0.001 \\
\hline Slope & $\begin{array}{l}\text { Warm } \\
\text { Cold }\end{array}$ & $\begin{array}{l}67.4 \\
48.5\end{array}$ & $\begin{array}{l}495.3 \\
717.5\end{array}$ & $\begin{array}{r}33.9 \\
1.3\end{array}$ & $\begin{array}{l}37.7 \\
41.8\end{array}$ & $\begin{array}{r}16.2 \\
4.2\end{array}$ & 0.04 & 0.041 \\
\hline Outer domain & $\begin{array}{l}\text { Warm } \\
\text { Cold }\end{array}$ & $\begin{array}{r}259.6 \\
87.1\end{array}$ & $\begin{array}{l}32.6 \\
62.2\end{array}$ & $\begin{array}{r}28.8 \\
9.1\end{array}$ & $\begin{array}{r}26.6 \\
0.8\end{array}$ & $\begin{array}{l}51.8 \\
14.9\end{array}$ & 0.13 & 0.003 \\
\hline Shelf & $\begin{array}{l}\text { Warm } \\
\text { Cold }\end{array}$ & $\begin{array}{r}3079.6 \\
463.2\end{array}$ & $\begin{array}{l}0.3 \\
0\end{array}$ & $\begin{array}{l}308.9 \\
343.7\end{array}$ & $\begin{array}{l}1.4 \\
0\end{array}$ & $\begin{array}{r}19.7 \\
5.6\end{array}$ & 0.22 & 0.001 \\
\hline
\end{tabular}


Cross-shelf assemblage structure was primarily associated with a geographic and/or salinity gradient that distinguished slope and shelf communities. Salinities are higher over the slope due to the oceanic influence of the Aleutian North Slope Current and lower on the shelf due to increased freshwater from the mainland and from the ACC flowing through Unimak Pass. The advection of slope waters onto the shelf can be seen in the spatial pattern of predicted species composition according to Axis 1 (Fig. 5A). A finger of slopederived species extended onto the shelf indicating larval transport through Bering Canyon. The crossshelf gradient, largely driven by differences in spawning habitat for slope and shelf species, appears resilient to environmental variability between warm and cold years.

The observation of unique slope and shelf assemblages corroborates previous patterns (Doyle et al. 2002) and provides information on spawning habitats of adult fish. Although larval Sebastes spp. (slope assemblage) cannot easily be identified to species, many adult distributions follow the shelf break and slope habitats in the southeastern Bering Sea (e.g. Pacific ocean perch Sebastes alutus; Brodeur 2001). Juvenile Atheresthes spp., comprising primarily arrowtooth flounder A. stomias and Kamchatka flounder A. evermanni, are widely distributed on the continental shelf and begin recruiting to the slope habitat after about age-4 (Wilderbuer et al. 2009). In recent years, their abundance has increased, leading to a greater trophic impact; adult arrowtooth flounder are known to be voracious predators on juvenile walleye pollock (Livingston \& Jurado-Molina 2000, Knoth \& Foy 2008, Ianelli et al. 2009). Larval pollock, however, were predominant in the shelf assemblage in our study, indicating spatial separation from adult arrowtooth flounder and from larval aggregations of Atheresthes spp. over the slope. Alaska plaice spawn along the north side of the Alaska Peninsula in April and May, and eggs and larvae drift north and northeast over the shelf (DuffyAnderson et al. 2010). While the drift trajectories vary interannually, the general current flow retains Alaska plaice within the shelf habitat.

The advection of ACC waters through Unimak Pass (Ladd et al. 2005) may affect the distribution of larval fish on the southeastern Bering Sea shelf. Water in Unimak Pass is similar to the outer domain water mass, especially in cold years, indicating directional flow of ACC water onto the outer Bering Sea shelf. Warm years with greater inflow of ACC water ( $\mathrm{T}$. Royer unpubl. data) may result in increased mixing and subsequent blending of water mass characteristics over the shelf (Fig. 2C). In cold years, inflow of ACC water is reduced, resulting in a clearer distinction of water masses (Fig. 2D).
Species entrained in, or advected by, ACC waters within Unimak Pass and the Bering Sea shelf included Pacific cod and northern rock sole, with higher overall abundances of these species in warm years. The trawling grounds around Unimak Pass are some of the most productive fishing areas for Pacific cod in the Bering Sea (Conners \& Munro 2008), and just northeast of Unimak Pass is a major spawning area (Shimada \& Kimura 1994). Pacific cod larvae caught in and near Unimak Pass in this study may reflect these wellknown spawning areas and/or reflect the contribution of Pacific cod spawned in the Gulf of Alaska to Bering Sea populations. Previous research on northern rock sole has identified spawning areas west of Unimak Pass along the Aleutian Islands and in the Gulf of Alaska with advection through Unimak Pass. Transport pathways follow the middle and outer shelf or flow eastward along the Alaska Peninsula (Lanksbury et al. 2007). Differential survival of northern rock sole depends on transport to adequate nursery grounds in the coastal domain (Wilderbuer et al. 2002, Lanksbury et al. 2007). Unfortunately, our sampling design cannot resolve whether these larvae originated in the Gulf of Alaska or were entrained in ACC waters within Unimak Pass and nearby spawning grounds. The impact of Gulf of Alaska larvae on Bering Sea populations, and the degree to which the populations are connected, are important ecological (i.e. competition, predation) and fisheries management (number of subpopulations) questions. To address the connectedness of these populations, future work tracking larvae from different spawning grounds using genetic markers, otolith microchemistry, or differential growth rates could improve the resolution of Gulf of Alaska larval contributions to Bering Sea populations.

The importance of nearshore habitats to Pacific cod, Bathymaster spp., and Pacific sand lance could reflect preferred spawning grounds of adult fish (e.g. Pacific cod; Shimada \& Kimura 1994). The onshore-offshore gradient in species composition was more difficult to interpret because correlations with individual species' CPUEs were weaker than for the other axes. In addition, the third NMDS axis captured residual variability not already accounted for in the first or second axes. However, the importance of nearshore habitat and an onshore-offshore gradient in species composition are biologically reasonable; therefore, we believe our interpretation of this axis is realistic.

The 3 spatial patterns of larval fish assemblages identified from the NMDS ordination axes are not exclusive; individual species can be correlated with more than one gradient, thereby capturing different influences on larval distribution. For example, Pacific sand lance was strongly correlated with the first and third axes. The first axis described Pacific sand lance 
as a shelf species, while the third axis further associated larval sand lance with the nearshore environment of the shelf habitat. Pacific cod was correlated with the second and third axes. The second axis highlighted the importance of ACC waters in the distribution of larval Pacific cod, while the third axis identified the nearshore environment as important, likely due to the spawning preferences of adult fish.

The analytical approach of multivariate ordination followed by GAMs as an exploratory regression technique successfully highlighted the main delineations of species compositions and modeled the response of the assemblage to environmental covariates. However, caution should be used when interpreting such results, as spurious (i.e. non-biologically relevant) outcomes are possible due to the flexible nature of GAMs. We are confident in our interpretations of the model results based on current knowledge of the Bering Sea ecosystem and believe our approach captured underlying mechanisms that determine larval fish species compositions in the southeastern Bering Sea.

While the timing of surveys used for this study was consistent across years, differential temperature effects on early life history events (e.g. spawning) could affect our interpretations. If colder temperatures result in delayed adult spawning activities or reduced rates of ichthyoplankton development, the fixed timing of our surveys could have been mismatched to the variable timing of larval production. Further, the timing of front formation in the region can also affect the distribution of larvae. For example, the Bering Sea Inner Front is a seasonally established hydrographic front that sets up in the vicinity of the $40 \mathrm{~m}$ isobath in spring and persists through late autumn (Schumacher \& Stabeno 1998, Kachel et al. 2002). We hypothesize that if cold conditions persist over the shelf into late spring, the timing of the set up of the Inner Front would be delayed, resulting in continued retention of larvae in northward moving currents along the 100 and $200 \mathrm{~m}$ isobaths and potentially out of our east-west survey area (Lanksbury et al. 2007).

The Oscillating Control Hypothesis (Hunt et al. 2002; revised in Hunt et al. in press) provides a theoretical framework within which to predict ecosystem responses to warm and cold regimes in the southeastern Bering Sea. In warm regimes with early ice retreat, stratified waters maintain production within the pelagic system (Mueter et al. 2006), resulting in enhanced survival of species such as walleye pollock (Hunt \& Stabeno 2002, Mueter et al. 2006, Moss et al. 2009). This is supported by the observation in the current study of high larval walleye pollock abundances in the warm years of 2002, 2003, and 2005. However, recent data show that in warm regimes, larger zooplankton taxa (e.g. large calanoid copepods and euphausiids) are less abundant, thus reducing growth rates and lipid reserves of young-of-year walleye pollock and thereby increasing predation risk and decreasing overwinter survival (Hunt et al. in press). Therefore, a discontinuity exists between early spring conditions (i.e. water column temperature and prey availability), larval abundance, and the abundance of age-1 walleye pollock observed following the first winter. Although higher abundances of larval walleye pollock may not be indicative of eventual year-class strength, community-level analyses may provide information on ecological interactions affecting specific populations.

Our study was the first to look at changes in larval fish community composition within the southeastern Bering Sea over a time period that included both warm and cold periods. Significant differences in assemblage structure were detected, supporting the hypothesis that early life stages may be primary indicators of environmental change. The biological shifts between warm and cold regimes are difficult to predict due to direct and indirect species responses; a better understanding of non-linear environmental effects will increase predictive and management capabilities. The eastern Bering Sea walleye pollock fishery averaged 1.31 million tons annually between 2000 and 2009 (Ianelli et al. 2009), representing the largest commercial fishery in the USA by weight. Therefore, it is important to understand the mechanisms underlying interannual variability in this stock.

Acknowledgements. We thank the officers and crew of NOAA's RVs 'Miller Freeman' and 'Oscar Dyson'. Funding was provided through NOAA's NPCREP and EcoFOCI programs, as well as the North Pacific Research Board (NPRB) Bering Sea Integrated Ecosystem Research Program (BSIERP). We thank 3 anonymous reviewers for providing helpful comments that improved the manuscript. This research is contribution EcoFOCI-0759 to NOAA's FisheriesOceanography Coordinated Investigations, NPRB 285, and BEST-BSIERP 17.

\section{LITERATURE CITED}

Akaike H (1973) Information theory as an extension of the maximum likelihood principle. In: BN Petrov, Csaki F (eds) Second Int Symp Information Theory. Akademiai Kiado, Budapest, p 267-281

Bacheler NM, Ciannelli L, Bailey KM, Duffy-Anderson JT (2010) Spatial and temporal patterns of walleye pollock (Theragra chalcogramma) spawning in the eastern Bering Sea inferred from egg and larval distributions. Fish Oceanogr 19:107-120

> Boeing WJ, Duffy-Anderson JT (2008) Ichthyoplankton dynamics and biodiversity in the Gulf of Alaska: responses to environmental change. Ecol Indic 8:292-302

Brander KM, Blom G, Borges MF, Erzini K and others (2003) Changes in fish distribution in the eastern North Atlantic: Are we seeing a coherent response to changing temperature? ICES Mar Sci Symp 219:260-273 
Brodeur RD (2001) Habitat-specific distribution of Pacific ocean perch (Sebastes alutus) in Pribilof Canyon, Bering Sea. Cont Shelf Res 21:207-224

Brodeur RD, Peterson WT, Auth TD, Soulen HL, Parnel MM, Emerson AA (2008) Abundance and diversity of coastal fish larvae as indicators of recent changes in ocean and climate conditions in the Oregon upwelling zone. Mar Ecol Prog Ser 366:187-202

Burnham KP, Anderson DR (2002) Model selection and multi-model inference: a practical information-theoretic approach. Springer-Verlag, New York, NY

> Chavez FP, Messié M (2009) A comparison of Eastern Boundary Upwelling Ecosystems. Prog Oceanogr 83:80-96

> Ciannelli L, Chan KS, Bailey KM, Stenseth NC (2004) Nonadditive effects of the environment on the survival of a large marine fish population. Ecology 85:3418-3427

Clarke KR, Gorley RN (2006) PRIMER v6: user manual/tutorial. PRIMER-E, Plymouth

- Coachman LK (1986) Circulation, water masses, and fluxes on the southeastern Bering Sea shelf. Cont Shelf Res 5: 23-108

Conners ME, Munro P (2008) Effects of commercial fishing on local abundance of Pacific cod (Gadus macrocephalus) in the Bering Sea. Fish Bull 106:281-292

> Coyle KO, Pinchuk AI, Eisner LB, Napp JM (2008) Zooplankton species composition, abundance and biomass on the eastern Bering Sea shelf during summer: the potential role of water-column stability and nutrients in structuring the zooplankton community. Deep-Sea Res II 55:1775-1791

Coyle KO, Eisner LB, Mueter FJ, Pinchuk AI and others (2011) Climate change in the southeastern Bering Sea: impacts on pollock stocks and implications for the Oscillating Control Hypothesis. Fish Oceanogr 20:139-156

> Doyle MJ, Mier KL, Busby MS, Brodeur RD (2002) Regional variation in springtime ichthyoplankton assemblages in the northeast Pacific Ocean. Prog Oceanogr 53:247-281

> Doyle MJ, Picquelle SJ, Mier KL, Spillane MC, Bond NA (2009) Larval fish abundance and physical forcing in the Gulf of Alaska, 1981-2003. Prog Oceanogr 80:163-187

> Duffy-Anderson JT, Busby MS, Mier KL, Deliyanides CM, Stabeno PJ (2006) Spatial and temporal patterns in summer ichthyoplankton assemblages on the eastern Bering Sea shelf 1996-2000. Fish Oceanogr 15:80-94

> Duffy-Anderson JT, Doyle MJ, Mier KL, Stabeno PJ, Wilderbuer TK (2010) Early life ecology of Alaska plaice (Pleuronectes quadrituberculatus) in the eastern Bering Sea: seasonality, distribution, and dispersal. J Sea Res 64:3-14

Field JG, Clarke KR, Warwick RM (1982) A practical strategy for analyzing multispecies distribution patterns. Mar Ecol Prog Ser 8:37-52

Hare SR, Mantua NJ (2000) Empirical evidence for North Pacific regime shifts in 1977 and 1989. Prog Oceanogr 47:103-145

Hunt GL Jr, Stabeno PJ (2002) Climate change and the control of energy flow in the southeastern Bering Sea. Prog Oceanogr 55:5-22

Hunt GL Jr, Stabeno PJ, Walters G, Sinclair E, Brodeur RD, Napp JM, Bond NA (2002) Climate change and control of the southeastern Bering Sea pelagic ecosystem. Deep-Sea Res II 49:5821-5853

Hunt GL Jr, Coyle KO, Eisner L, Farley EV and others (in press) Climate impacts on eastern Bering Sea food webs: a synthesis of new data and an assessment of the Oscillating Control Hypothesis. ICES J Mar Sci

Ianelli JN, Barbeaux S, Honkalehto T, Kotwicki S, Aydin K, Williamson N (2009) Assessment of the walleye pollock stock in the Eastern Bering Sea. In: Stock assessment and fishery evaluation report for the groundfish resources of the Bering Sea/Aleutian Islands regions. North Pacific Fishery Management Council, Anchorage, AK, p 49-148 IPCC (Intergovernmental Panel on Climate Change) (2007) Climate Change 2007: the physical science basis. Solomon S, Qin D, Manning M, Chen Z and others (eds) Contribution of Working Group I to the Fourth Assessment Report of the Intergovernmental Panel on Climate Change. Cambridge University Press, Cambridge

Iverson RL, Coachman LK, Cooney RT, English TS and others (1979) Ecological significance of fronts in the southeastern Bering Sea. In RJ Livingston (ed) Ecological processes in coastal and marine systems. Plenum Press, New York, NY, p 437-466

Kachel NB, Hunt GL Jr, Salo SA, Schumacher JD, Stabeno PJ, Whitledge TE (2002) Characteristics and variability of the inner front of the southeastern Bering Sea. Deep-Sea Res II 49:5889-5909

Knoth BA, Foy RJ (2008) Temporal variability in the food habits of arrowtooth flounder (Atheresthes stomias) in the Western Gulf of Alaska. US Dept of Commerce, Springfield, VA, NOAA Tech Memo NMFS-AFSC 184

Kruskal JB (1964) Multidimensional scaling by optimizing goodness of fit to a nonmetric hypothesis. Psychometrika 29:1-27

Ladd C, Hunt GL Jr, Mordy CW, Salo SA, Stabeno PJ (2005) Marine environment of the eastern and central Aleutian Islands. Fish Oceanogr 14(Suppl. 1):22-38

> Lanksbury JA, Duffy-Anderson JT, Mier KL, Wilson MT (2005) Ichthyoplankton abundance, distribution, and assemblage structure in the Gulf of Alaska during September 2000 and 2001. Estuar Coast Shelf Sci 64: 775-785

> Lanksbury JA, Duffy-Anderson JT, Mier KL, Busby MS, Stabeno PJ (2007) Distribution and transport patterns of northern rock sole, Lepidopsetta polyxystra, larvae in the southeastern Bering Sea. Prog Oceanogr 72:39-62

Livingston PA, Jurado-Molina J (2000) A multispecies virtual populations analysis of the eastern Bering Sea. J Mar Sci 57:294-299

Minchin PR (1987) An evaluation of the relative robustness of techniques for ecological ordination. Vegetatio 69:89-101

Moss JH, Farley EV, Feldman AM, Ianelli JN (2009) Spatial distribution, energetic status, and food habits of eastern Bering Sea age-0 walleye pollock. Trans Am Fish Soc 138:497-505

> Mueter FJ, Litzow MA (2008) Sea ice retreat alters the biogeography of the Bering Sea continental shelf. Ecol Appl 18:309-320

Mueter FJ, Ladd C, Palmer MC, Norcross BL (2006) Bottomup and top-down controls of walleye pollock (Theragra chalcogramma) on the Eastern Bering Sea shelf. Prog Oceanogr 68:152-183

Mueter FJ, Hunt GL Jr, Litzow MA (2007) The Eastern Bering Sea shelf: a highly productive seasonally ice-covered sea. ICES CM2007/D:04, available at www.ices.dk/products/ CMdocs/CM-2007/D/D0407.pdf

Mueter FJ, Broms C, Drinkwater KF, Friedland KD, Hare JA, Hunt GL Jr, Melle W (2009) Ecosystem responses to recent oceanographic variability in high-latitude Northern Hemisphere ecosystems. Prog Oceanogr 81:93-110

> Napp JM, Baier CT, Brodeur RD, Coyle KO, Shiga N, Mier K (2002) Interannual and decadal variability in zooplankton communities of the southeast Bering Sea shelf. Deep-Sea Res II 49:5991-6008

Perry AL, Low PJ, Ellis JR, Reynolds JD (2005) Climate change and distribution shifts in marine fishes. Science 308:1912-1915 
Pörtner HO, Berdal B, Blust R, Brix O and others (2001) Climate induced temperature effects on growth performance, fecundity and recruitment in marine fish: developing a hypothesis for cause and effect relationships in Atlantic cod (Gadus morhua) and common eelpout (Zoarces viviparus). Cont Shelf Res 21:1975-1997

Royer TC (1982) Coastal freshwater discharge in the Northeast Pacific. J Geophys Res 87(C3):2017-2021

Schumacher JD, Stabeno PJ (1998) The continental shelf of the Bering Sea. In: Robinson AR, Brink KH (eds) The sea, Vol 11 - the global coastal ocean: regional studies and syntheses. John Wiley \& Sons, New York, NY, p 789-822

Shima M, Bailey KM (1994) Comparative analysis of ichthyoplankton sampling gear for early life stages of walleye pollock (Theragra chalcogramma). Fish Oceanogr 3:50-59

Shimada AM, Kimura DK (1994) Seasonal movements of Pacific cod, Gadus macrocephalus, in the eastern Bering Sea and adjacent waters based on tag-recapture data. Fish Bull 92:800-816

Spencer PD (2008) Density-independent and densitydependent factors affecting temporal changes in spatial distributions of eastern Bering Sea flatfish. Fish Oceanogr 17:396-410

Stabeno PJ, Bond NA, Kachel NB, Salo SA, Schumacher JD (2001) On the temporal variability of the physical environ-

Editorial responsibility: Antonio Bode,

A Coruña, Spain ment over the south-eastern Bering Sea. Fish Oceanogr 10:81-98

Stabeno PJ, Reed RK, Napp JM (2002) Transport through Unimak Pass, Alaska. Deep-Sea Res II 49:5919-5930

Stabeno PJ, Hunt GL Jr, Napp JM, Schumacher JD (2006) Physical forcing of ecosystem dynamics on the Bering Sea shelf. In: Robinson AR, Brink KH (eds) The sea, Vol 14the global coastal ocean: interdisciplinary regional studies and syntheses, Part B. Harvard University Press, Cambridge, MA, p 1177-1212

> Weingartner TJ, Danielson SL, Royer TC (2005) Freshwater variability and predictability in the Alaska Coastal Current. Deep-Sea Res II 52:169-191

- Wilderbuer TK, Hollowed AB, Ingraham WJ Jr, Spencer PD, Conners ME, Bond NA, Walters GE (2002) Flatfish recruitment response to decadal climatic variability and ocean conditions in the eastern Bering Sea. Prog Oceanogr 55: 235-247

Wilderbuer TK, Nichol DG, Aydin K (2009) Arrowtooth flounder. In: Stock assessment and fishery evaluation report for the groundfish resources of the Bering Sea/Aleutian Islands regions. North Pacific Fishery Management Council, Anchorage, AK, p 677-740

Wood SN (2006) Generalized additive models: an introduction with R. Chapman \& Hall/CRC, Boca Raton, FL

Submitted: September 11,2010; Accepted: December 22, 2010 Proofs received from author(s): March 10, 2011 